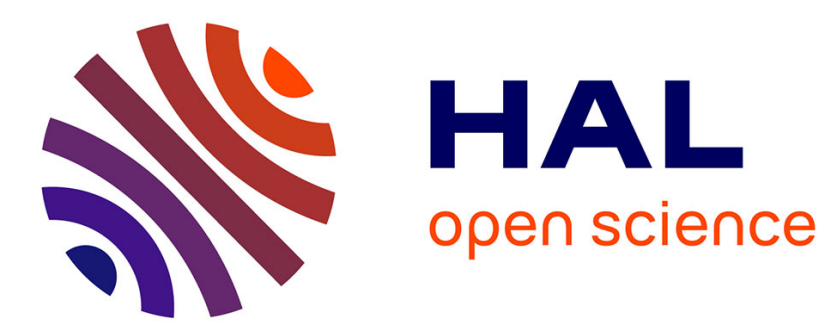

\title{
Zinc Geochemical Cycling in a Phosphorus-Rich Ocean During the Early Ediacaran
}

Haifeng Fan, Hanjie Wen, Chaoyi Xiao, Ting Zhou, Christophe Cloquet, Xiangkun Zhu

\section{- To cite this version:}

Haifeng Fan, Hanjie Wen, Chaoyi Xiao, Ting Zhou, Christophe Cloquet, et al.. Zinc Geochemical Cycling in a Phosphorus-Rich Ocean During the Early Ediacaran. Journal of Geophysical Research. Oceans, 2018, 123 (8), pp.5248-5260. 10.1029/2018JC014068 . hal-02915124

\section{HAL Id: hal-02915124 https://hal.science/hal-02915124}

Submitted on 31 Dec 2021

HAL is a multi-disciplinary open access archive for the deposit and dissemination of scientific research documents, whether they are published or not. The documents may come from teaching and research institutions in France or abroad, or from public or private research centers.
L'archive ouverte pluridisciplinaire HAL, est destinée au dépôt et à la diffusion de documents scientifiques de niveau recherche, publiés ou non, émanant des établissements d'enseignement et de recherche français ou étrangers, des laboratoires publics ou privés.

$$
\text { Copyright }
$$




\section{Journal of Geophysical Research: Oceans}

\section{RESEARCH ARTICLE}

10.1029/2018JC014068

\section{Key Points:}

- We report $Z n$ isotope compositions of dolostone, phosphorite, and organic-rich shale from the Doushantuo Formation, South China

- Phosphorite may represent an important sink of isotopically heavy $\mathrm{Zn}$ in a phosphorus-rich ocean during Earth history

- Zinc geochemical cycling in the early Ediacaran oceans could be very similar to that of modern oceans

Supporting Information:

- Supporting Information S1

- Data Set S1

Correspondence to:

H. Fan,

fanhaifeng@mail.gyig.ac.cn

Citation:

Fan, H., Wen, H., Xiao, C., Zhou, T., Cloquet, C., \& Zhu, X. (2018). Zinc geochemical cycling in a phosphorus-rich ocean during the early Ediacaran. Journal of Geophysical Research: Oceans, 123, 5248-5260. https://doi.org/10.1029/2018JC014068

Received 13 APR 2018 Accepted 27 JUN 2018 Accepted article online 17 JUL 2018 Published online 6 AUG 2018

\section{Zinc Geochemical Cycling in a Phosphorus-Rich Ocean During the Early Ediacaran}

\author{
Haifeng Fan ${ }^{1}$ (D), Hanjie Wen ${ }^{1,2}$, Chaoyi Xiao ${ }^{1,2}$, Ting Zhou ${ }^{1}$, Christophe Cloquet ${ }^{3}$, and Xiangkun Zhu ${ }^{4}$ \\ 'State key Laboratory of Ore Deposit Geochemistry, Institute of Geochemistry, Chinese Academy of Sciences, Guiyang, \\ China, ${ }^{2}$ College of Earth and Planetary Sciences, University of Chinese Academy of Sciences, Beijing, China, ${ }^{3}$ Centre de \\ Recherches Petrographiques et Geochimiques, Vandoeuvre-les-Nancy Cedex, France, ${ }^{4}$ MNR Key Laboratory of Isotope \\ Geology, Institute of Geology, Chinese Academy of Geological Sciences, Beijing, China
}

Abstract During the early Ediacaran, there was a large influx of phosphorus into the oceans and a resultant high phosphorus concentration in seawater, where multicellular eukaryotes may have been the primary type of marine productivity. The eukaryotes could play a critical role in regulating $\mathrm{Zn}$ cycling and isotopes. To establish Zn geochemical cycling patterns in the phosphorus-rich ocean, this study investigates $\mathrm{Zn}$ isotopic signatures of shallow water phosphorite that contains phosphatized microfossils (Weng'an biota) and deep-water shale from the Doushantuo Formation. Our results indicate that phosphorite commonly preserves heavier $\mathrm{Zn}$ isotope composition, with an average of $0.80 \%$. The positive $\delta^{66} \mathrm{Zn}$ values in phosphorites may be ascribed to $\mathrm{Zn}$ isotope fractionation associated with the complexation of $\mathrm{Zn}$ with phosphate and the adsorption of isotopically heavy Zn onto Fe-Mn oxides and organism's surfaces. We argue that phosphorite may represent an important sink of isotopically heavy $\mathrm{Zn}$ in a phosphorus-rich ocean during Earth history. Meanwhile, deep-water organic-rich shale shows an enrichment of isotopically light $\mathrm{Zn}$ with an average of $0.23 \%$, which may be attributed to sulfide precipitation in mid-depth environment. The organic-rich shale may represent an isotopically light $Z n$ sink. In addition, the highest $\delta^{66} \mathrm{Zn}$ value $(0.45 \%$ o) in a euxinic black shale may indicate that $Z n$ isotope signal of anoxic deep water is similar to that of modern deep seawater. If that is the case, it suggests that $\mathrm{Zn}$ geochemical cycling in the early Ediacaran oceans was similar to that of modern oceans.

\section{Introduction}

In the modern ocean, dissolved $\mathrm{Zn}$ occurs as main organic/inorganic complexed $\mathrm{Zn}$ and minor free $\mathrm{Zn}^{2+}$ ion. It has a short residence time (11,000 years) and a total mass of $1.35 \times 10^{21} \mathrm{~kg}$ in global oceans (Little, Vance, et al., 2014). The surface seawater is characterized by depletion of dissolved $\mathrm{Zn}$ and strongly variable $\mathrm{Zn}$ isotope compositions (Conway \& John, 2015; John \& Conway, 2014; Samanta et al., 2017). These variations in $\delta^{66} \mathrm{Zn}$ values could be associated with complexation with organic ligands (Jouvin et al., 2009), biological uptake (John et al., 2007; Samanta et al., 2017), particle scavenging (John \& Conway, 2014), and input from river and aerosols (John \& Conway, 2014; Little, Sherman, et al., 2014). The regeneration of $\mathrm{Zn}$ from sinking biological particles enhances the concentration of dissolved $\mathrm{Zn}$ and results in a uniform $\mathrm{Zn}$ isotopic composition in deep-water environments (John \& Conway, 2014; Moynier et al., 2017; Zhao et al., 2014). In marine environments, primary productivity and organic carbon burial rates are sensitive to phosphorus levels in seawater and influxes of phosphorus from the weathering of continental crust, where phosphorus is typically a limiting nutrient for marine productivity on geological timescales (Horton, 2015; Robbins et al., 2016, and references therein). Recent investigations have indicated that there was a large influx of phosphorus into the oceans during the early Ediacaran (Konhauser et al., 2007; Planavsky et al., 2010; Reinhard et al., 2017), which may be attributed to the accelerated glacial weathering (Planavsky et al., 2010) and the weathering of large igneous provinces (Cox et al., 2016; Horton, 2015).

During the early Ediacaran, large volume of phosphorites was deposited worldwide in the phosphorus-rich ocean (Cook \& Shergold, 1984). Carbonate and black shale with high phosphorus levels were also deposited during the early Ediacaran (Reinhard et al., 2017; Shimura et al., 2014). Ediacaran phosphatized microfossils (multicellular eukaryotes) have also been reported worldwide, including the Weng'an biota that is hosted in the phosphorite of the Doushantuo Formation in south China (Xiao et al., 2014, and references therein). Previous studies have suggested that the eukaryotes became important in a narrow time interval between 
the Sturtian and Marinoan snowball Earth glaciations (Brocks et al., 2017) and eukaryotes commonly have higher $\mathrm{Zn}$ quota and $\mathrm{Zn} / \mathrm{P}$ on average due to abundant $\mathrm{Zn}$ finger protein, compared to prokaryote (Dupont et al., 2010; Twining \& Baines, 2013). Moreover, $\mathrm{Zn}$ is co-located in organic fraction with phosphorus in eukaryotic phytoplankton, and the lengthscale of $Z n$ regeneration is similar to phosphorus (e.g., de Souza et al., 2018; Vance et al., 2017). Therefore, both biological utilization of light $\mathrm{Zn}$ isotope by eukaryotes and adsorption of heavy isotope by organism's surface have been used to explain the heavier Zn isotope composition measured in cap carbonate (635 Ma) sequences (John et al., 2016; Kunzmann et al., 2013). Here we propose that multicellular eukaryotes associated with elevated phosphorus concentrations in seawater may play a critical role in regulating $\mathrm{Zn}$ geochemical cycle and $\mathrm{Zn}$ isotope fractionation during the early Ediacaran.

To test our hypothesis, we investigated shallow-water phosphorite that contains phosphatized microfossils (the Weng'an biota) and deep-water shale from the Doushantuo Formation. We measured $\mathrm{Zn}$ isotope compositions of phosphorite that were deposited on the shallow marine platform and shale from the slope and basin sections of the Yangtze Platform, south China. Based on the results of this study, we constructed Zn geochemical cycling pattern in a phosphorus-rich Ediacaran ocean.

\section{Geological Setting}

In South China, most of the phosphorite ore deposits that occur in the Ediacaran Doushantuo Formation (635-550 Ma) are distributed in the proximal side of the shelf lagoon (e.g., Baokang, north of Yichang in Hubei Province) and in the distal side of the shelf lagoon within the shelf shoaling complex (Weng'an and Kaiyang in Guizhou Province; Jiang et al., 2011; Figure 1). Carbonate with high phosphorus content also formed on the Yangtze platform during the early Ediacaran (Shimura et al., 2014). In contrast, the open-ocean side of the shelf margin, toward the slope and basin, was characterized by much more black shale and lower abundance of phosphorite. However, phosphorus concentrations in the slope shale from the Wuhe section occasionally exceed $1 \%$. Therefore, there may have been a phosphorus-rich ocean during deposition of the early Ediacaran Doushantuo Formation. The high phosphorus concentrations in seawater would enhance primary productivity. For example, shallow-water facies (on the platform to shelf) preserved the Weng'an biota in Weng'an phosphorite (Xiao et al., 1998), Chadian in southern Shanxi Province (Xiao et al., 1999), and Baokang in Hubei Province (Zhou et al., 2001).

\subsection{The Shallow Water Phosphorites}

The Weng'an phosphorite ore deposit of the Doushantuo Formation exposed in the Guizhou Province, south China, have previously been described in detail (e.g., Chen et al., 2003, 2004; Xiao et al., 2014). The stratigraphic column for the Datang section (N:26 $57^{\prime} 1.57^{\prime \prime}, \mathrm{E}: 107^{\circ} 21^{\prime} 40.70^{\prime \prime}$ ) includes, moving up from the base, the following (Figure 1a): (1) a 5- to 10-m-thick cap dolostone unconformably overlies the tillite of the Cryogenian Nantuo Formation; (2) a 1- to 5-m-thick lower phosphorite layer contains laminated to banded structures and has a $\mathrm{P}_{2} \mathrm{O}_{5}$ concentration of $>25 \mathrm{wt}$.\%; (3) a 2- to 4-m-thick dolostone layer separates the Weng'an phosphorite ore deposit into lower and upper phosphorite layers; (4) a 3- to 10-m-thick upper phosphorite layer including black phosphorite (approx. $2.5 \mathrm{~m}$ thick), gray-white pelletoidal dolomitic phosphorite, and phosphorous dolomite; (5) the zebra phosphorous dolomite marks the top of the Doushantuo Formation and is overlain by dolostone of the Dengying Formation. The lower age bound for the upper phosphorite layer has been constrained to $599 \pm 4 \mathrm{Ma}$ (Barfod et al., 2002), and the upper age bound is constrained to $576 \pm 14 \mathrm{Ma}$ (Chen et al., 2004). The unit contains abundant microfossils, such as embryonic, larval, and adult animal forms, multicellular thallophytes, giant acritarchs, and spheroidal chlorophyte fossils that are well preserved in the upper phosphorite layer (Xiao et al., 1998, 2014, and references therein). However, no animal forms have been found in the lower phosphorite layer, which may indicate a major evolutionary, faunal, or local environmental change during deposition of the Doushantuo Formation (Chen et al., 2003). The upper phosphorite interval in the Yingping section in the Weng'an area is similar to the Datang section.

\subsection{The Deeper Water Shales}

The slope and basin sections are dominated by shale, as well as a few dolostone layers and rare phosphorite layers. The Wuhe section characterized by slope deposits also exhibits phosphorus enrichment with the concentration of $P>10,000$ ppm during deposition of the Doushantuo Formation. The Wuhe section of 


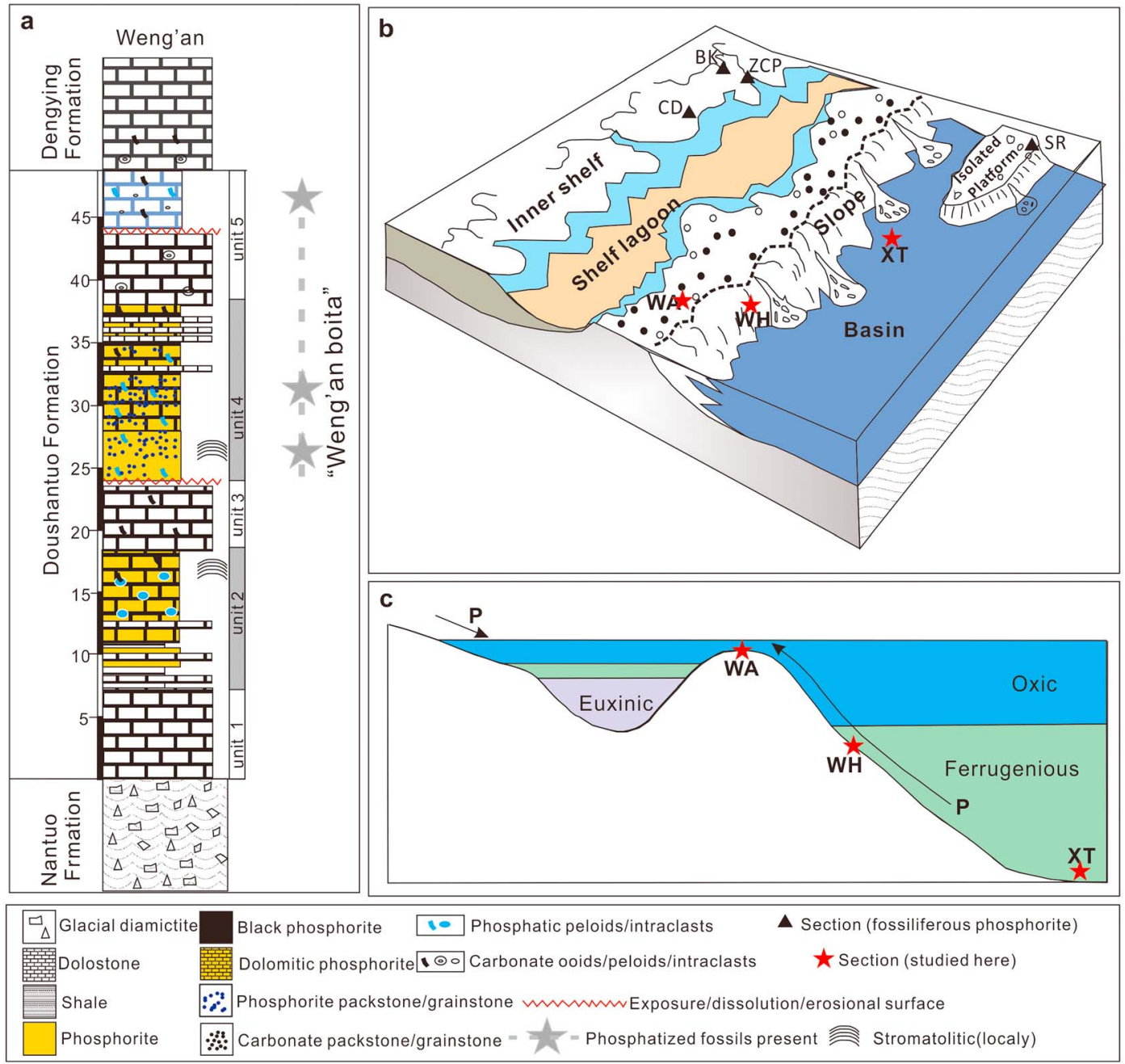

Figure 1. Simplified stratigraphic sequence of the Datang section in the Weng'an ore field (a) and depositional environments at the Weng'an (Datang section), Wuhe (WH), and Xiangtan (XT) sections: (b) depositional model and (c) transect along the Yangtze platform, with arrows showing possible source of phosphorus. Occurrences of Doushantuo phosphorite with fossils: Baokang (BK), Chadian (CD), Zhangcunping (ZCP), Shangrao (SR), and Weng'an (WA). Pb-Pb isochron ages from Barfod et al. (2002) and Chen et al. (2003). Modified from Xiao et al. (2014). The redox conditions were constructed based on previous published papers (Han \& Fan, 2015; Li et al., 2010; Sahoo et al., 2016).

the Doushantuo Formation is also underlain by the tillite of the Nantuo Formation and has a thickness of approximately $120 \mathrm{~m}$. The boundaries are characterized by cap carbonate rocks $(2.5 \mathrm{~m}$ thick) at the base and the organic-rich black shale $(5 \mathrm{~m}$ thick) at the top, and the remainder is primarily composed of interbedded black shale and carbonate (Han \& Fan, 2015; Sahoo et al., 2016). Only three samples were collected from the basinal Xiangtan section. The stratigraphy of the Xiangtan section was previously described (Han \& Fan, 2015) and is not described in detail here. Both the Wuhe (slope deposits) and Xiangtan (basinal deposits) sections were interpreted to be deposited in ferruginous conditions with intermittent euxinic conditions (Han \& Fan, 2015; Sahoo et al., 2016, Figure 1).

\section{Analytical Methods}

\subsection{Zn Isotope Analysis}

The $\mathrm{Zn}$ associated with carbonate $\left(\mathrm{Zn}_{\mathrm{carb}}\right)$ in dolostone and phosphorite was leached in $1.5 \mathrm{~N}$ acetic acid over a $120^{\circ} \mathrm{C}$ hot plate for $10 \mathrm{hr}$ according to published methods (Kunzmann et al., 2013; Pichat et al., 2003). The bulk phosphorite was also extracted using $6 \mathrm{~N}$ hydrochloric acid over a $120^{\circ} \mathrm{C}$ hot plate for $24 \mathrm{hr}$, leading to 

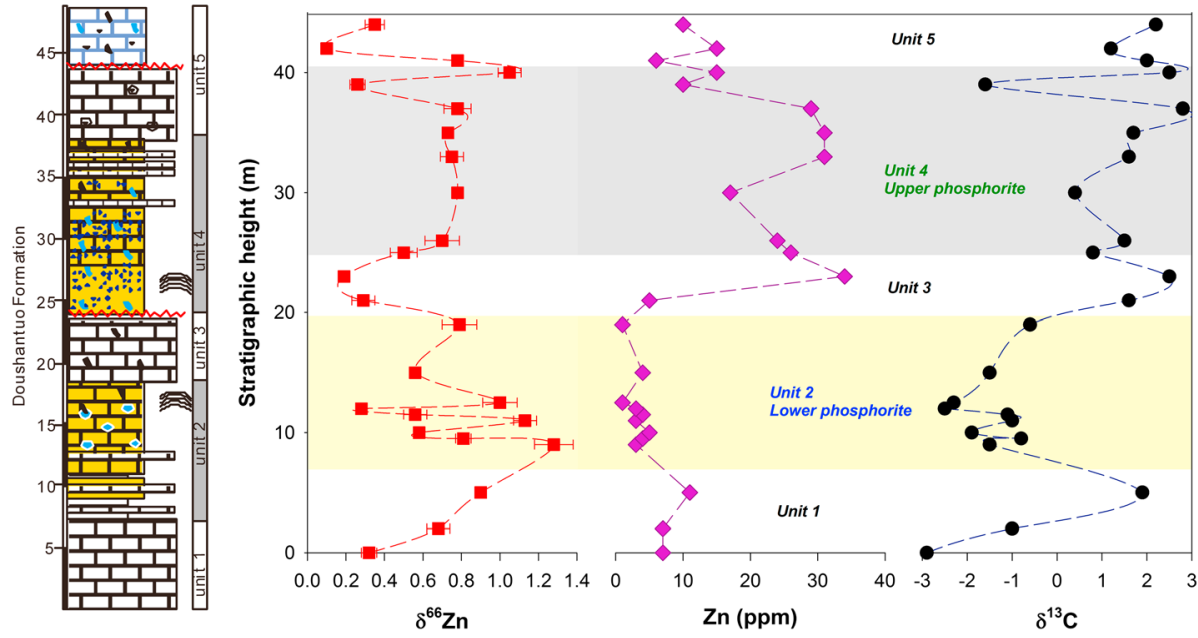

Figure 2. $\delta^{66} \mathrm{Zn}$ and $\delta^{13} \mathrm{C}$ variations and $\mathrm{Zn}$ concentrations along the Datang section, in the Weng'an ore field. The yellow and gray zones represent the lower and upper phosphorite layers, respectively. The base $(0 \mathrm{~m})$ is the contact between the Nantuo Formation diamictite and the overlying cap dolostone. We have only several samples in other sections.

extraction of $\mathrm{Zn}$ bound in carbonate, phosphate, and oxide. Two separate aliquots of some shale samples were digested in $6 \mathrm{~N}$ hydrochloric acid and aqua regia, respectively. The extracted solution was completely evaporated after centrifuging, then the solids were dissolved with $1 \mathrm{~mL}$ of $2 \mathrm{M} \mathrm{HCl}+0.001 \% \mathrm{H}_{2} \mathrm{O}_{2}$ for the chemical purification of $\mathrm{Zn}$. The procedure to attain the chemical purity of $\mathrm{Zn}$ using AGMP-1 anion exchange resin (100-200 mesh) followed the method outlined by Tang et al. (2006). The $\mathrm{Zn}$ concentrations and isotopic ratios were measured using a Neptune MC-ICP-MS at the Institute of Geochemistry, Chinese Academy of Sciences. A standard-sample bracketing approach was applied to correct the instrumental mass discrimination when an IRMM3702 Zn solution was used as working standard. All $\delta^{66} \mathrm{Zn}$ values are reported compared to JMC Lyon $\mathrm{Zn}$ standard, based on the published difference between IRMM3702 Zn and JMC Lyon $\mathrm{Zn}\left(\Delta^{66} \mathrm{Zn}_{\text {IRMM3702-JMC Lyon } \mathrm{Zn}}=+0.30 \%\right.$, Vance et al., 2016; Moynier et al., 2017). $\delta^{66} \mathrm{Zn}$ values of BHVO-2 (0.30 $\pm 0.03 \%$ ), COQ-1 $(0.28 \pm 0.06 \%$ ), and NIST $683(0.16 \pm 0.05 \%$ ) are consistent with previous publications (Moynier et al., 2017; Wang et al., 2017, and reference therein).

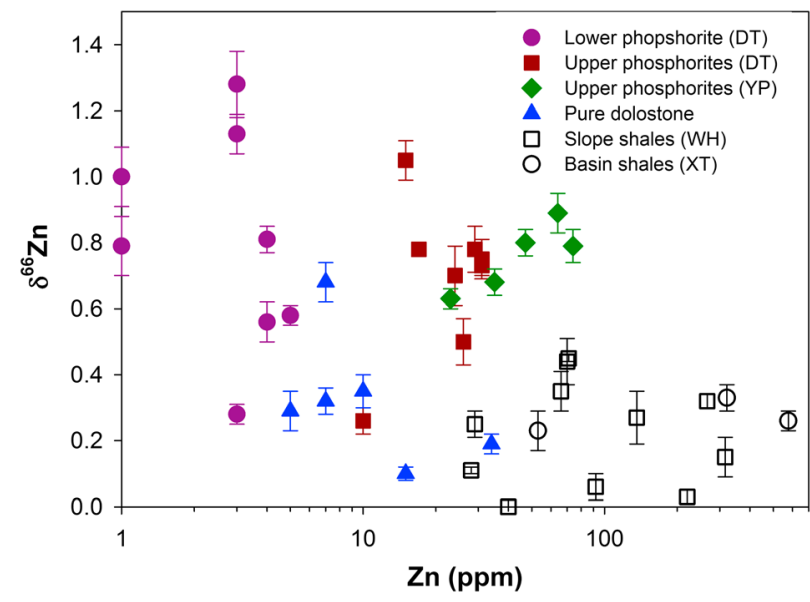

Figure 3. The $\delta^{66} \mathrm{Zn}$ values plotted against $\mathrm{Zn}$ concentrations of all samples from the investigated sections. High $\delta^{66} \mathrm{Zn}$ values and low $\mathrm{Zn}$ concentrations are preserved in the shallow water phosphorites, whereas low $\delta^{66} \mathrm{Zn}$ values and high $\mathrm{Zn}$ concentrations are recorded in the deep-water organic-rich shales. DT = the Datang section, $\mathrm{YP}=$ the Yingping section, $\mathrm{WH}=$ the Wuhe section, and $\mathrm{XT}=$ The Xiangtan section.

\subsection{Carbon and Oxygen Isotopes and Element Concentration}

Carbon and oxygen isotopes were measured using a Finnigan MAT-253 at the Third Institute of Oceanography, State Oceanic Administration. Isotopic results are expressed in the standard per mil (\%o) notation relative to V-PDB $\left(\delta^{13} \mathrm{C}_{\text {carb}}, \delta^{18} \mathrm{O}_{\text {carb }}\right)$. Uncertainties determined through multiple measurements of NBS-19 (TS-limestone) were better than $0.05 \%$ o ( $1 \mathrm{sd}$ ). The concentrations of major elements ( $\mathrm{Al}, \mathrm{Ca}, \mathrm{Mg}, \mathrm{Fe}, \mathrm{P}$, and $\mathrm{Mn}$ ) were determined using an X-ray fluorescence spectrometer at the ALS Chemex (Guangzhou) Company Limited. Two geo-standards (NIST 694 for phosphate rock; GSR-5 for shale) were used to monitor precision and accuracy. Total $\mathrm{Zn}$ concentration in all samples was measured using ICP-MS in the Institute of Geochemistry, Chinese Academy of Sciences (Qi et al., 2000). Total S and organic carbon were determined using a C-S element analytical instrument (CS-314).

\section{Results}

All data are listed in the Table S1 in the supporting information and presented in Figures 2 and $3 . \delta^{66} \mathrm{Zn}$ values of $\mathrm{Zn}$ associated with carbonate $\left(\delta^{66} \mathrm{Zn}_{\text {Carb }}\right)$ in dolostone range from $0.19 \%$ o to $0.68 \%$, with an average of $0.33 \%$. The average $\delta^{66} \mathrm{Zn}_{\text {Carb }}$ value in P-dolostone $\left(\mathrm{P}_{2} \mathrm{O}_{5}>3 \%\right)$ and 
phosphorite is $0.71 \%$, with a wide range from $0.56 \%$ o to $1.28 \%$, which is mostly higher than that of pure dolostone. Almost all phosphorites from the Datang section exhibit positive $\delta^{66} \mathrm{Zn}_{\text {bulk }}$ values, mostly between $0.50 \%$ and $1.28 \%$, with an average of $0.80 \%$ except for two low values (DTA-07, 0.28\%o; DTB-18, 0.26\%o) (Figure 2). However, the lower and upper phosphorite layers show obviously different $\mathrm{Zn}, \mathrm{Fe}$, and $\mathrm{S}$ concentrations. The upper phosphorite layers display a higher $\mathrm{Zn}$ content (13-38 ppm) and lower Fe (0.06-0.19\%) and S (0.04-0.18\%) concentrations, whereas the lower phosphorite layers display a low $\mathrm{Zn}$ content (2-5 ppm) and higher Fe (0.41-1.83\%) and S (0.15-2.27\%) concentrations. The upper phosphorite layers from the Yingping section also show high $\mathrm{Zn}$ concentrations (35-153 ppm) and $\delta^{66} \mathrm{Zn}_{\text {bulk values }}$ $(0.63-1.07 \%)$ and low Fe (0.07-0.23\%) and S (0.14-0.21\%), which is consistent with the upper phosphorite layers in the Datang section. Moreover, the lower and upper phosphorite layers in the Datang section exhibit a distinct carbon isotope composition (Figure 2), which is consistent with previous study (Guo et al., 2005). In contrast, almost all organic-rich shales have high $\mathrm{Zn}$ concentrations (50 to $577 \mathrm{ppm}$ ) and low $\delta^{66} \mathrm{Zn}_{\text {bulk }}$ values $\left(0.00-0.45 \%\right.$ o) with an average of $0.23 \%$ o (Figure 3). Moreover, $\delta^{66} \mathrm{Zn}$ values of these shales leached by $6 \mathrm{~N}$ hydrochloric acid are very similar to that of leached by aqua regia (Table S1).

\section{Discussion}

\subsection{Zn Isotope Composition of Zn Associated With Carbonate}

$\mathrm{Zn}$ isotope fractionation between $\mathrm{Zn}$ associated with carbonate and dissolved $\mathrm{Zn}$ ions has not been well constrained yet. Assuming no net or weak $\mathrm{Zn}$ isotopic fractionation between carbonate and dissolved $\mathrm{Zn}$, heavy $\mathrm{Zn}$ isotope compositions in modern and ancient carbonate may reflect strong biological utilization of dissolved Zn in surface seawater (Kunzmann et al., 2013; Liu et al., 2017; Pichat et al., 2003) or may indicate the balance of organic particle and sulfide sinks in the ocean system (John et al., 2016). However, both experimental and theoretical studies indicate an observable $\mathrm{Zn}$ isotope fractionation between carbonate and dissolved $Z n$. Veeramani et al. (2015) found a small $Z n$ isotope fractionation $\left(\Delta^{66} Z n_{\text {hydrozincite-solution }}\right.$ $=+0.18 \%$ ) between hydrozincite and dissolved $\mathrm{Zn}$ during the inorganic precipitation experiment. In addition, natural observation has shown that the $\delta^{66} \mathrm{Zn}$ values of biological hydrozincite in mine drainage from Rio Naracauli in Sardinia, Italy, are 0.35\%o heavier than those in ambient water (Wanty et al., 2013). A larger $\mathrm{Zn}$ isotope fractionation has been reported in recent experiments, where the adsorption of $\mathrm{Zn}$ onto calcite can fractionate $\mathrm{Zn}$ isotopes, with $\Delta^{66} \mathrm{Zn}_{\text {adsorbed-solution }}=0.41 \pm 0.18 \%$ at low ionic strength and $0.73 \pm 0.08 \%$ at high ionic strength (Dong \& Wasylenki, 2016). Nevertheless, all observed $\mathrm{Zn}$ isotope fractionation under natural conditions are much different from that of theoretical calculations $\left(\Delta^{66} \mathrm{Zn}_{\text {hydrozincite-solution }}=1.0 \%\right.$ o, Fujii et al., 2011, 2014; $\Delta^{66} \mathrm{Zn}_{\text {smithsonite-solution }}=-0.73 \%$ o, Ducher et al., 2016).

The $\delta^{66} \mathrm{Zn}_{\text {Carb }}$ values in dolostone are ranging from $0.19 \%$ o to $0.68 \%$, which is mostly lower than that of modern biogenic carbonate from the eastern equatorial Pacific $(0.31 \%$ o to $1.34 \%$; Pichat et al., 2003), Permian-Triassic boundary argillaceous and micritic limestone in the Meishan section from south China (0.83\%o to $1.21 \%$; Liu et al., 2017), and Ediacaran cap carbonate $(10-13 \mathrm{~m})$ from the Nuccaleena Formation in the Adelaide Rift Complex of South Australia (0.68 to 0.87\%o; John et al., 2016; Kunzmann et al., 2013). Zn concentrations in our dolostones are much lower than those of modern biogenic carbonates, Permian limestones, and Ediacaran cap carbonates. Therefore, it is possible that $\mathrm{Zn}$ bound in carbonate is just in the crystal lattice of calcite or dolomite in our dolostones. The range of $\delta^{66} \mathrm{Zn}_{\text {Carb }}$ values may indicate at least $0.50 \%$ isotope fractionation during the substitution of $\mathrm{Zn}$ into dolostone, assuming these dolostones precipitated from seawater with a homogeneous $\mathrm{Zn}$ isotope composition.

It is noted that the $\delta^{66} \mathrm{Zn}_{\text {Carb }}$ values $(0.56 \%$ o to $1.28 \%$ ) in P-dolostone (> 3\%) and phosphorite are mostly higher than that of pure dolostone. A little dolomite minerals were observed in these phosphorites (Xiao et al., 2018). The substitution of $\mathrm{Zn}$ into dolomite could not explain these high $\delta^{66} \mathrm{Zn}_{\text {Carb }}$ values in P-dolostone ( $>3 \%$ ) and phosphorite. A previous study predicts that phosphate ligands preferentially complex heavier $\mathrm{Zn}$ isotope, with $\Delta^{66} \mathrm{Zn}_{\text {phosphate-solution }}=1.0 \%$ o (Fujii \& Albarède, 2012). In addition, $\delta^{66} \mathrm{Zn}_{\text {Carb }}$ values in phosphorite are very close to that of bulk phosphorite (Table S1). Therefore, the exchange of $\mathrm{Zn}$ between dolomite and phosphate during diagenesis may possibly enhance $\delta^{66} \mathrm{Zn}_{\text {Carb }}$ values in P-dolostone $(>3 \%)$ and phosphorite. Here we suggest that the wide range $\delta^{66} \mathrm{Zn}_{\text {Carb }}$ values in dolostone could reflect $\mathrm{Zn}$ isotope fractionation during the substitution of $\mathrm{Zn}$ into dolostone, rather 
than $\mathrm{Zn}$ isotope composition of Ediacaran seawater. The higher $\delta^{66} \mathrm{Zn}_{\text {Carb }}$ values in P-dolostone ( $\left.>3 \%\right)$ and phosphorite than those of pure dolostone may be attributed to the exchange of $\mathrm{Zn}$ between dolomite and phosphate during diagenesis.

\subsection{Heavy Zn Isotopic Composition of Phosphorite}

In phosphorite, carbonate fluorapatite is the dominant phosphate mineral that forms during early diagenesis (Föllmi, 1996). In upwelling environments with high productivity in the overlying water column, phosphogenesis can occur in pore waters saturated with phosphate sourced from decaying organic matter (Föllmi, 1996; Jarvis et al., 1994). The close relationship between organism and phosphogenesis was also demonstrated in many cases by the occurrence of phosphatized stromatolites (Föllmi, 1996, and references therein). In non-upwelling phosphogenic environments, pore water phosphate is generally regulated by iron redox pumping (Föllmi, 1996; Heggie et al., 1990; Nelson et al., 2010, and references therein).

However, $\mathrm{Zn}$ distribution in phosphorite is not well understood yet. Jarvis et al. (1994) suggested that $\mathrm{Zn}$ could occur in the apatite structure through the replacement of $\mathrm{Ca}^{2+}$ cations. Recent study observed high $\mathrm{Zn}$ concentration in phosphatic particles from late Paleocene-early Eocene phosphorites in Tunisia, using LA-ICP-MS (63-325 ppm; Garnit et al., 2012). In addition to Zn mainly present in phosphatic grains, Zn may also be transferred into phosphorite via adsorption of $Z n$ onto Fe-Mn oxides and incorporated in or adsorbed on organic matter. Consequently, $\mathrm{Zn}$ isotope fractionation during the complexation with phosphate and the adsorption of $\mathrm{Zn}$ onto Fe-Mn oxides and organic matter are discussed.

\subsubsection{Complexation of $\mathbf{Z n}$ by Phosphate in Seawater}

In general, the fates of $\mathrm{Zn}$ and phosphate seem to be strongly connected. For example, $\mathrm{Zn}$ and phosphate coexist in the organic matter of diatom, and the lengthscale of $\mathrm{Zn}$ regeneration is similar to phosphate (de Souza et al., 2018; Vance et al., 2017). Theoretical calculations have indicated that $Z n$ phosphate species preferentially concentrate isotopically heavy $\mathrm{Zn}$, whereas $\mathrm{Zn}^{2+}$ and malate species concentrate the lighter $\mathrm{Zn}$ isotopes, without pH dependence (Fujii et al., 2014; Fujii \& Albarède, 2012). $\mathrm{Zn}$ isotope fractionation between $\mathrm{Zn}$ bonding with phosphate and dissolved $\mathrm{Zn}^{2+}$ in solution is on the order of $1 \%$ at $5<\mathrm{pH}<8$ (Fujii \& Albarède, 2012). However, recent experiments exhibited a smaller $\mathrm{Zn}$ isotope fractionation between inorganic hopeite $\left[\mathrm{Zn}_{3}\left(\mathrm{PO}_{4}\right)_{2} \cdot 4 \mathrm{H}_{2} \mathrm{O}\right]$ and dissolved $\mathrm{Zn}{ }^{2+}$ at $\mathrm{pH}=7.2$, with $\Delta^{66} \mathrm{Zn}_{\text {hopeite-solution }}=0.25 \%$ o (Veeramani et al., 2015). This fractionation of $\mathrm{Zn}$ isotopes due to phosphates has been argued to explain the heavier $\mathrm{Zn}$ isotope compositions in plant root than leaves (Fujii \& Albarède, 2012; Veeramani et al., 2015) and the positive excursion of $\delta^{66} \mathrm{Zn}$ in the $2.9-2.5 \mathrm{Ga}$ banded iron formation (Pons et al., 2013).

In this study, the bulk phosphorites yield heavier $\mathrm{Zn}$ isotope composition, mostly between $0.50 \%$ o to $1.28 \%$. Our results show that phosphorite exhibits much higher $\delta^{66} \mathrm{Zn}_{\text {bulk }}$ values than modern oxic sediments (at $129 \mathrm{~m}$ depth) without phosphate in the Black sea (0.22\%o to 0.36\%o, Vance et al., 2016), which may reflect the significant influence that phosphate has on $\mathrm{Zn}$ isotope fractionation. Therefore, $\mathrm{Zn}$ isotope fractionation between phosphate complexing ligands and free $\mathrm{Zn}^{2+}$ ion in seawater is a likely first-order control on the heavier $\mathrm{Zn}$ isotope compositions observed in phosphorites. However, the obviously different $\mathrm{Zn}$ concentrations in the lower and upper phosphorite layers may be associated with the adsorption of $\mathrm{Zn}$ onto organism and/or Fe-Mn oxides.

\subsubsection{Zn Isotope Fractionation Associated With Organism}

Early experimental study showed that diatoms in freshwater and seawater were preferentially enriched in isotopically heavy $\mathrm{Zn}\left(\Delta^{66} \mathrm{Zn}_{\text {cell-solution }}=0.27 \%\right.$ o to $0.35 \%$ ), no matter what $\mathrm{Zn}$ was fixed in cells or adsorbed on the surface (Gélabert et al., 2006). This is confirmed by Köbberich and Vance (2017), who found that extremely low $\mathrm{Zn}$ uptake rate could result in the enrichment of isotopically heavy $\mathrm{Zn}$ in diatom, but more rapid $\mathrm{Zn}$ uptake rate did not produce $\mathrm{Zn}$ isotope fractionation between diatom and the external free $\mathrm{Zn}$ pool. Recently, the GEOTRACES investigation demonstrated either invariant or decreasing $\delta^{66} \mathrm{Zn}$ values toward the surface in modern ocean (Conway \& John, 2014, 2015; Zhao et al., 2014), which may also suggest no net $\mathrm{Zn}$ isotope fractionation when $\mathrm{Zn}$ is fixed into a diatom opal (Archer et al., 2016; Zhao et al., 2014), or the adsorption of heavy $Z n$ isotope on organic particle surface (John \& Conway, 2014; Köbberich \& Vance, 2017). Other experiments have suggested that lighter $\mathrm{Zn}$ isotopes are preferred in diatom cell $\left(\Delta^{66} Z n_{\text {cell-solution }}=-0.80 \%\right.$ o to $-0.2 \%$ ), but heavier $\mathrm{Zn}$ isotopes are preferred on cell or 

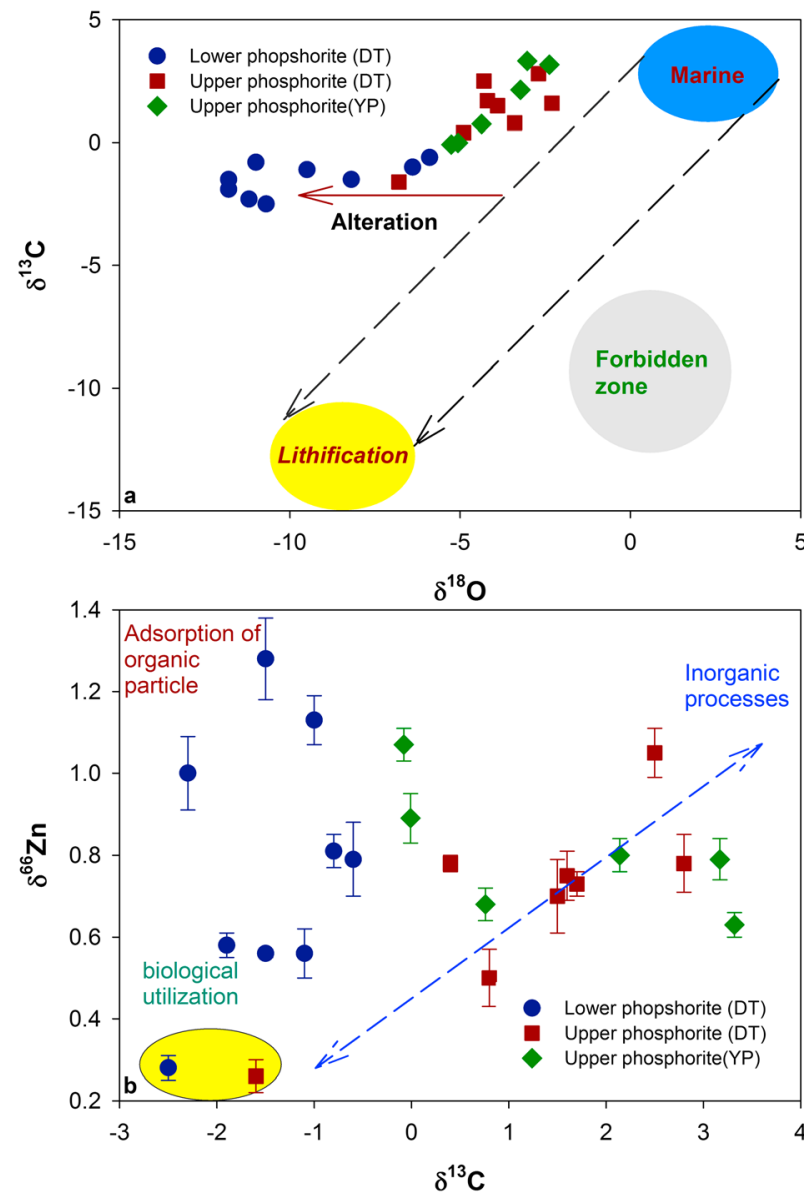

Figure 4. Correlation of $\delta^{13} \mathrm{C}$ with $\delta^{18} \mathrm{O}$ (a) and $\delta^{66} \mathrm{Zn}$ values (b) for all phosphorites in the Weng'an area. (a) The blue area (marine) is dominantly marine pore fluids; black dash lines reflect significant mixing with meteoric water. Both areas define the "lithification" zone (Knauth \& Kennedy, 2009). Later deep burial and/or metamorphic alteration produce data to the left of the lithification domain, as shown by the red arrow. No samples are located in the forbidden zone in this study. (b) Three possible mechanisms may be identified, including (1) the inorganic adsorption or complexation is reflected by the high $\delta^{66} \mathrm{Zn}$ and positive $\delta^{13} \mathrm{C}$ values, (2) the organic adsorption is suggested by high $\delta^{66} \mathrm{Zn}$ and negative $\delta^{13} \mathrm{C}$ values, (3) the biological utilization is indicated by the low $\delta^{66} \mathrm{Zn}$ and negative $\delta^{13} \mathrm{C}$ values. DT $=$ the Datang section and $\mathrm{YP}=$ the Yingping section. organic particle surface during adsorption (Gélabert et al., 2006; John et al., 2007; John \& Conway, 2014). Natural observation across the north-south transect of the Tasman Sea also indicated preferential uptake of lighter Zn isotopes by phytoplankton (Samanta et al., 2017), which can explain the heavy $\mathrm{Zn}$ isotope composition in surface water. In summary, lighter $\mathrm{Zn}$ isotopes were preferentially taken up by phytoplankton, but surface adsorption of $\mathrm{Zn}$ on the organic particle surface leads to a heavier isotope composition.

Organisms are generally considered to play an important role in phosphogenesis (Föllmi, 1996). The positive correlation of C and O isotopes may indicate diagenetic alteration in our phosphorites (Figure 4a). During early diagenesis, buried organic carbon would be degraded, which may decrease the $C$ isotope composition to negative values, but depending on carbonate content in phosphorite. Due to the alteration of organic carbon, we cannot evaluate the affection of organism on $\mathrm{Zn}$ concentrations in our phosphorites. Assuming that the biological uptake and adsorption of $Z n$ onto organic particle surface dominated the $\mathrm{Zn}$ isotope fractionation of phosphorite, these phosphorites should exhibit negative $\delta^{13} \mathrm{C}$ values and variable $\delta^{66} \mathrm{Zn}$ values. The varied $\delta^{66} \mathrm{Zn}$ values in the lower phosphorite layers could be associated with main organic particle adsorption and minor biological utilization processes (Figure 4b). In contrast, inorganic adsorption may strongly regulate $\mathrm{Zn}$ isotope composition in the upper phosphorite layers (Figure $4 \mathrm{~b}$ ). It is interesting that the Weng'an biota (multicellular eukaryotes) is present in the upper phosphorite layers. However, the relationship between $\delta^{66} \mathrm{Zn}$ and $\delta^{13} \mathrm{C}$ values did not indicate a significant biological utilization of $\mathrm{Zn}$ by the Weng'an biota. In summary, a kinetic biological uptake driven $\mathrm{Zn}$ isotope fractionation probably is not playing an important role in our phosphorites.

\subsubsection{Fe-Redox Pumping Mechanism}

Previous experimental studies have suggested preferential adsorption of isotopically heavy $\mathrm{Zn}$ onto Fe-Mn oxides relative to the host solution, with $\Delta^{66} \mathrm{Zn}_{\text {oxide-seawater }}=+0.6 \%$ o for hematite (Pokrovsky et al., 2005$),+0.29 \%$ and $+0.5 \%$ o for goethite and 2-line ferrihyrite, respectively (Juillot et al., 2008), and $0.16 \%$ o to $3.0 \%$ o for birnessite at high ionic strength (Bryan et al., 2015). Moreover, Fe-Mn crusts are commonly isotopically heavy in $\mathrm{Zn}\left(\delta^{66} \mathrm{Zn}=0.9-1.0 \%\right.$ o $)$ compared to deep water $\left(\delta^{66} \mathrm{Zn}=+0.5 \%\right.$; Maréchal et al., 2000; Little, Sherman, et al., 2014). The heavy Zn isotope compositions of modern Fe-Mn crust and nodules may be attributed to the change in the coordinated environment of the $\mathrm{Zn}$ ion during adsorption onto Fe-Mn oxides (Bryan et al., 2015; Little, Sherman, et al., 2014) and/or the role of phosphates as carrier of heavy Zn and as the "master regulators" of biological productivity in soils (Chadwick et al., 1999; Maréchal et al., 2000).

The enrichment of phosphate in seawater and pore water is usually ascribed to Fe-redox pumping, during which adsorbed phosphate on Fe-oxides would be released beneath Fe-redox boundary (Föllmi, 1996; Nelson et al., 2010). The adsorption of $\mathrm{Zn}$ onto Fe-Mn oxides could play an important role in transferring isotopically heavy $\mathrm{Zn}$ into phosphorites. The same enrichment in heavy $\mathrm{Zn}$ isotopes has been observed in the lower and upper phosphorites, although the iron and $\mathrm{Zn}$ concentrations are very different in the two phosphorite layers (Figure 2). The lower phosphorite was deposited under anoxic condition without Ce negative anomalies, where the occurrence of diagenetic pyrite indicates Fe-oxide reduction and bacterial sulfate reduction during diagenesis (Xiao et al., 2018). In this condition, the released Fe could be fixed as pyrite without an additional release into seawater, which results in higher Fe concentrations in these phosphorites. In this case, the isotopically heavy $\mathrm{Zn}$ that adsorbed onto Fe-oxides in shallow water would 

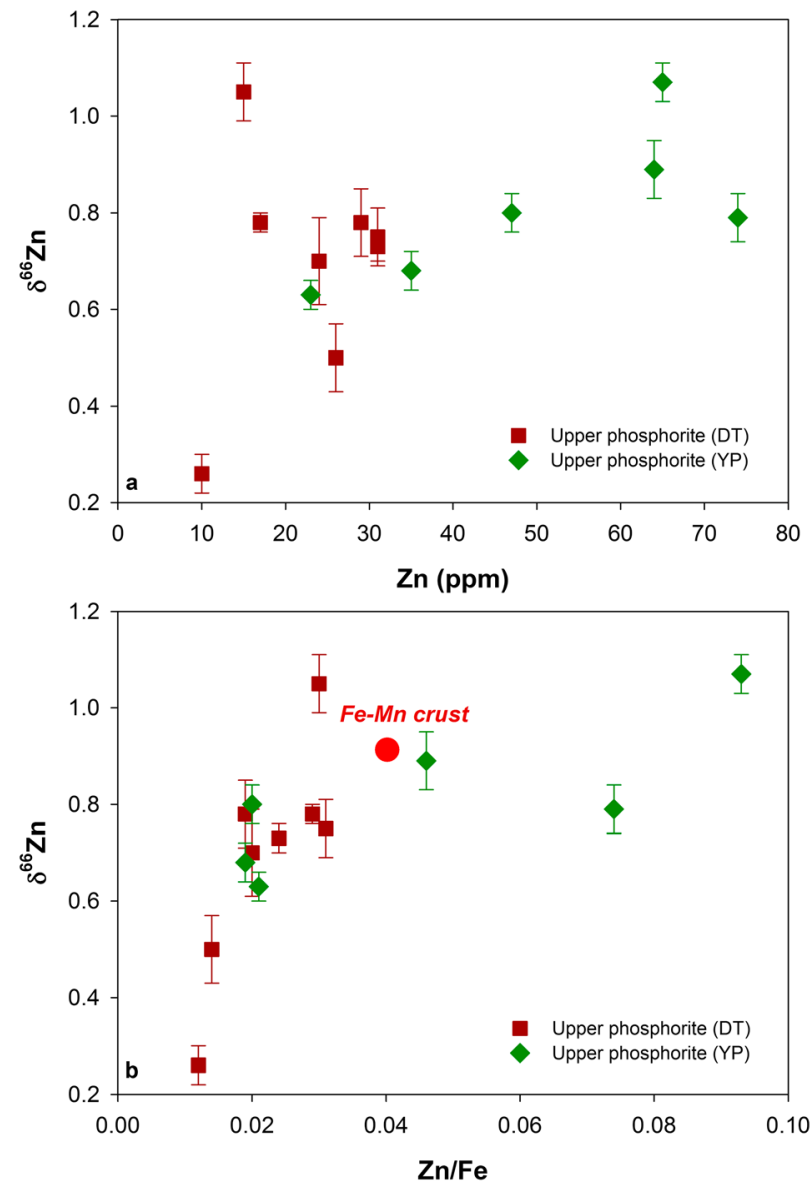

Figure 5. Plots of measured $\delta^{66} \mathrm{Zn}$ values versus $\mathrm{Zn}$ concentrations and $\mathrm{Zn} /$ Fe ratios for the upper phosphorite layers from the Datang and Yingping sections in the Weng'an area. DT = the Datang section and YP = the Yingping section. be fixed as sulfide phase. However, the low $\mathrm{Zn}$ concentrations in these phosphorites may suggest a minor contribution of Fe-Mn oxide adsorption.

It is interesting that there are broadly positive correlations of $\delta^{66} \mathrm{Zn}$ values with $\mathrm{Zn} / \mathrm{Fe}$ ratios and $\mathrm{Zn}$ concentrations in the upper phosphorite (Figure 5). The upper phosphorite layers were deposited under suboxic/oxic condition with Ce negative anomalies, where only Fe-oxides occurred, without pyrite (Xiao et al., 2018). These phosphorites contain abundant coated phosphatic nodules, revealing reworking and winnowing cycles post-deposition (Pufahl \& Grimm, 2003). An iron-redox pump may be a critical mechanism that enriches phosphate and $\mathrm{Zn}$ in pore water due to the release of phosphate and $\mathrm{Zn}$ that has been adsorbed onto Fe oxide. The released Fe would return to pore water or seawater due to the absence of bacterial sulfate reduction and re-oxidation in suboxic water, but the released Zn may be quantitatively/partially fixed with phosphate or carbonate. Such a repeated redox interaction may explain higher $\mathrm{Zn}$ and lower Fe concentrations as well as broadly positive correlation between $\delta^{66} \mathrm{Zn}$ values, $\mathrm{Zn} / \mathrm{Fe}$ ratios, and $\mathrm{Zn}$ concentrations in the upper phosphorite layers from the Yingping section (Figure 5). In regard to the upper phosphorite layers from the Datang section, correlations between $\delta^{66} \mathrm{Zn}$ values and $\mathrm{Zn} / \mathrm{Fe}$ ratios and $\mathrm{Zn}$ concentrations are not very strong, which may suggest a weak influence of the Fe-Mn oxides adsorption on $\mathrm{Zn}$ concentrations and isotopes in these phosphorites, compared to that of the Yingping section.

\subsection{The Lighter Zn Isotopic Composition in Organic-Rich Shales}

The organic-rich shales from the slope and basin sections exhibit overall lower $\delta^{66} \mathrm{Zn}_{\text {bulk }}$ values $(0.23 \%$ ) and a narrow range in values from $0.06 \%$ to $0.45 \%$ o (Figure 3 ). New data are consistent with data reported for different-aged marine shales from the Montagne Noire of France (0.20\% to $0.32 \%$ o), sapropel from the Mediterranean (0.26\% to $0.29 \%$ o), deep-sea surface sediments from the central Atlantic Ocean $(0.17 \%$ o to 0.35\%; Maréchal et al., 2000), and organism-rich continental margin sediments from the eastern Pacific margin (-0.15\%o to $0.32 \%$; Little et al., 2016). Little et al. (2016) suggested that $\delta^{66} \mathrm{Zn}$ values of authigenic $\mathrm{Zn}$ in these organic-rich shales should be mostly between $-0.4 \%$ and $+0.1 \%$, which was determined by calibrating lithogenic and authigenic $\mathrm{Zn}$ using $\mathrm{Zn}$-Al systematics.

Two mechanisms have been suggested to explain the light $\mathrm{Zn}$ isotope composition of organic-rich shales. First, biologic uptake may prefer to incorporate light $Z n$ isotopes in phytoplankon (John et al., 2007). However, more and more evidence from surface water suggested that the scavenging of $\mathrm{Zn}$ by organic particles may dominate the distribution of $\mathrm{Zn}$ isotope in surface water (Conway \& John, 2014, 2015; Zhao et al., 2014), resulting in enrichment of heavy $Z n$ isotopes on the surfaces of the organisms. Therefore, biological involvement might not explain the light $\mathrm{Zn}$ isotopic signals that are observed in organic matter rich shales (Little et al., 2016).

Second, authigenic $\mathrm{Zn}$ mineral precipitation could be a potential mechanism that results in light $\mathrm{Zn}$ isotope enriched in minerals. For example, $\mathrm{Zn}$ sulfides (sphalerite and wurtzite) are typically rich in light $\mathrm{Zn}$ isotopes, with $\Delta^{66} \mathrm{Zn}_{\text {sulfide-solution }}=\sim-0.3$ to $-0.6 \%$ o (Fujii et al., 2011). Recent experiments and natural studies have also reported the same fractionation direction, with $\Delta^{66} \mathrm{Zn}_{\text {sulfide-solution }}=\sim-0.3 \%$ o (Archer \& Vance, 2004; Jamieson-Hanes et al., 2017; Veeramani et al., 2015). This potential mechanism has been widely used to explain lower $\delta^{66} \mathrm{Zn}$ values in sphalerites (Veeramani et al., 2015) and organic-rich shales (Little et al., 2016; Vance et al., 2016). If $\mathrm{Zn}$ precipitation in deep seawater is dominated by $\mathrm{Zn}$ sulfides, then the $\mathrm{Zn}$ isotope composition of the $\mathrm{Zn}$ sulfide fraction should be equal to or lighter than that of the water column. Previous studies have suggested that the deep-water Wuhe section may have been deposited under 
ferruginous conditions with intermittent euxinic conditions (Han \& Fan, 2015; Sahoo et al., 2016), where the dissolved $\mathrm{Zn}$ could be scavenged from seawater by $\mathrm{H}_{2} \mathrm{~S}$ that was reduced from dissolved sulfate. If the dissolved $\mathrm{Zn}$ was quantitatively precipitated as sulfide under sulfidic condition, the sediments would be isotopically similar to seawater-derived Zn (Tang et al., 2016; Vance et al., 2016). For example, the euxinic sediments in the Black Sea record the $\mathrm{Zn}$ isotopic signature of the deep ocean, which has been attributed to the quantitative removal of $\mathrm{Zn}$ from the water column by $\mathrm{Zn}$ sulfide precipitation (Vance et al., 2016). Therefore, the highest $\delta^{66} \mathrm{Zn}$ value $(0.45 \%$ ) of black shale (WH-43) deposited in euxinic condition may proximately reflect $\mathrm{Zn}$ isotope signal of ambient seawater. However, other lower $\delta^{66} \mathrm{Zn}$ values of our shales precipitated from ferruginous condition could indicate $\mathrm{Zn}$ isotope fractionation between $\mathrm{Zn}$ sulfides and the water column. In this case, the average $\delta^{66} \mathrm{Zn}$ value of deep water may be close to $0.5 \%$, based on the average $\delta^{66} \mathrm{Zn}_{\text {bulk }}$ value (0.23\%) of our shales and the previous observed $\mathrm{Zn}$ isotope fractionation between sulfide and solution with $\Delta^{66} \mathrm{Zn}_{\text {sulfide-solution }}=\sim-0.3 \%$ o (Archer \& Vance, 2004; Jamieson-Hanes et al., 2017; Veeramani et al., 2015).

\subsection{Implications for Zn Geocycling in a Phosphorus-Rich Ediacaran Ocean}

Scott et al. (2013) proposed that the Zn concentration in seawater was broadly uniform over time and has maintained near-modern levels that were several orders of magnitude above the biolimiting concentration, which has been confirmed by other investigations regarding $\mathrm{Zn}$ concentrations and $\mathrm{Zn} / \mathrm{Fe}$ ratios in banded iron formation (Robbins et al., 2013, 2016). Recently, investigation of $\mathrm{Zn}$ isotope signature of banded iron formations has suggested that the $\mathrm{Zn}$ geochemical cycle has been near steady state for the last 1.8-1.9 Ga (Pons et al., 2013). If it is the case, near-modern weathering intensities and output of $\mathrm{Zn}$ can be assumed for the early Ediacaran ocean. Little, Vance, et al. (2014) estimated that the average $\delta^{66} \mathrm{Zn}$ value for the riverine influx $\left(5.9 \times 10^{8} \mathrm{~mol} /\right.$ year) is $0.33 \%$ o. However, the deep ocean has a homogenous $\mathrm{Zn}$ isotope composition, with an average of 0.55\%o (e.g., Conway \& John, 2014; Moynier et al., 2017; Zhao et al., 2014), which requires an oceanic sink that is isotopically light for Zn (Little, Sherman, et al., 2014; Little, Vance, et al., 2014). Recently, sulfide minerals in organic-rich sediments that are deposited at continental margins have been recognized as potential sinks for light Zn isotopes (Conway \& John, 2014; Little et al., 2016).

In this study, shallow-water phosphorites have heavy Zn isotopic composition (0.80\%) and low Zn concentrations. The relatively uniform $\delta^{66} \mathrm{Zn}$ values are consistent with the average of modern Fe-Mn crusts and nodules $(0.90 \%$ ) and biogenic carbonates $(0.91 \%$ ) , which are heavier than modern deep-water. The oxic output associated with Fe-Mn oxides would remove approximately $70 \%$ of the total dissolved $\mathrm{Zn}$ from the oceans, which is an order of magnitude higher that than contained in carbonates (Little, Vance, et al., 2014). Recent publications have suggested that the early Ediacaran ocean in south China was characterized by a redox-stratified structure, where shallow water was oxic and deep water was ferruginous (Han \& Fan, 2015; Li et al., 2010). In the phosphate-rich shallow water, the complexation of $\mathrm{Zn}$ with phosphate may be the first-order control for the heavy $\mathrm{Zn}$ isotope composition in our phosphorites. The adsorption of $\mathrm{Zn}$ onto Fe-Mn oxides may also play an important role in increasing $\delta^{66} \mathrm{Zn}$ values of phosphorites, especially for the upper phosphorite layers (Figure 6). During the early Ediacaran, enhanced marine phosphate concentrations would have resulted in higher primary productivity and increased organic carbon burial because phosphorus ultimately limits net primary productivity (Planavsky et al., 2010). Additionally, $Z n$ is a key life trace metal and is a component in a wide variety of metallo-peptides and polymerases. Many $Z n$ metalloenzymes are used in processes involving DNA and RNA syntheses (Dupont et al., 2010; Robbins et al., 2016, and reference therein). However, the Weng'an biota (multicellular eukaryotes) preserved in the upper phosphorite may not play an important role in enhancing the biological utilization of dissolved $\mathrm{Zn}$ in surface seawater. This observation could suggest that the biological utilization of dissolved $\mathrm{Zn}$ in seawater before the occurrence of the Weng'an biota is similar to that of after. In such phosphate-rich and high productivity conditions, dissolved $\mathrm{Zn}$ that bonds with phosphate in seawater would also be removed by the adsorption onto organism. During these processes, isotopically heavy $\mathrm{Zn}$ would be enriched in the phosphorite, but isotopically light $\mathrm{Zn}$ would remain in the surface water (Figure 6). This interpretation is supported by observations made from profiles from the North Pacific Ocean (Conway \& John, 2015), the Southern Ocean (Zhao et al., 2014), and the North Atlantic Ocean (John \& Conway, 2014), where shallow water has a light Zn isotope composition, which may reflect scavenging on phytoplankton or shallow remineralization. Therefore, phosphorite may represent an important sink of isotopically heavy $\mathrm{Zn}$ in the phosphate-rich shallow water environment. 


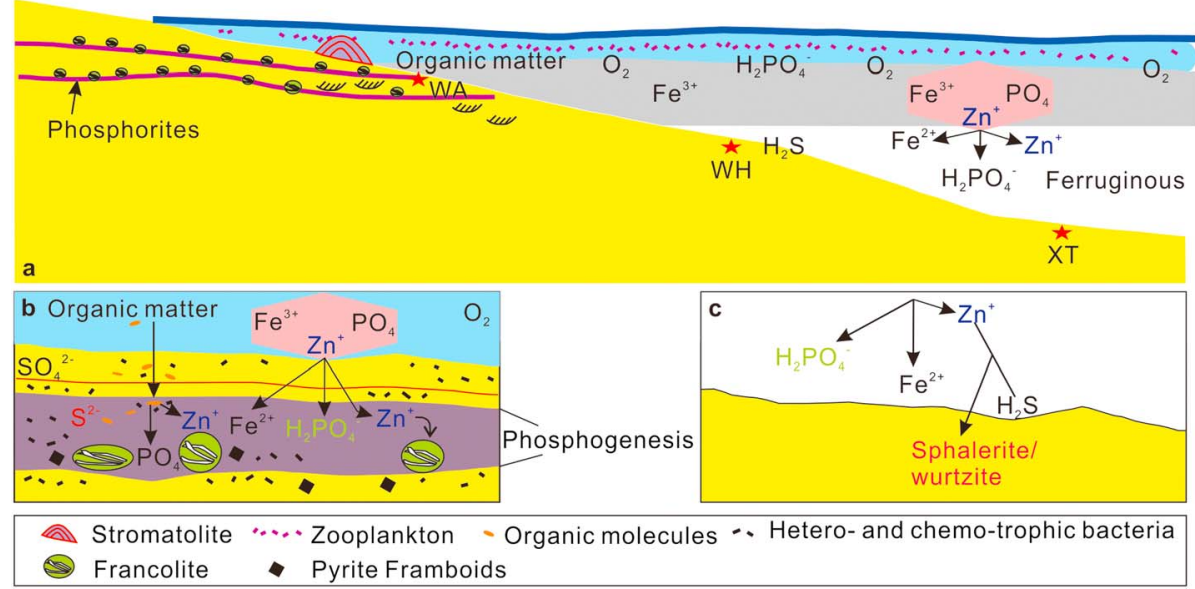

Figure 6. $\mathrm{Zn}$ geochemical cycling in a phosphorus-rich ocean during the early Ediacaran. Dissolved $\mathrm{Zn}$ bonded with phosphate (such as $\mathrm{ZnH}_{3}\left(\mathrm{PO}_{4}\right)_{2}\left(\mathrm{H}_{2} \mathrm{O}\right)_{4}{ }^{-}, \mathrm{ZnH}_{2} \mathrm{PO}_{4}\left(\mathrm{H}_{2} \mathrm{O}\right)_{5}{ }^{+}$) was delivered to the seafloor by (1) photoautotrophically, chemoautotrophically, and heterotrophically produced organic matter, (2) the adsorption onto organisms and Fe-(oxyhydr) oxide particles. The later mechanisms would transfer isotopically heavy $\mathrm{Zn}$ into phosphorites and deep ferruginous water (a). Zn phosphate species adsorbed onto Fe-(oxyhydr)oxide particles and organisms would be released into pore water, accompanied with reduction of Fe-(oxyhydr)oxide and degradation of organic matter in the phosphogenesis zone of the Weng'an (WA) phosphorite ore area (b). Subsequently, Zn phosphate species would enter into francolite, which may preserve a heavy $\mathrm{Zn}$ isotopic composition. However, the regeneration of $\mathrm{Zn}$ phosphate species sorbed on organism and Fe-(oxyhydr)oxide occurred in the deep part of the water column, where dissolved $\mathrm{Zn}$ ions may quantitatively or partially precipitate as smithsonite and/or sulfides (sphalerite/wurtzite) with near zero or $\sim 0.3 \%$ fractionation $\left(\Delta^{66} \mathrm{Zn}_{\text {water column-mineral }}\right)$ between these $\mathrm{Zn}$ minerals and deep seawater in the Wuhe (WH) and Xiangtan (XT) sections (c). This diagram is modified from Hiatt et al. (2015).

Conversely, the adsorption of $\mathrm{Zn}$ bonded with phosphate onto Fe-Mn oxides and organic particles could also transfer isotopically heavy $\mathrm{Zn}$ into deep water (Figure 6), which could lead to an increase in dissolved $\mathrm{Zn}$ and phosphate concentrations in deep water. However, the redox conditions of the deep-water environment would regulate $\mathrm{Zn}$ levels in the deep part of the water column. For example, euxinic conditions have caused lower dissolved $\mathrm{Zn}$ concentrations in the deep water of the Black Sea (Vance et al., 2016). In contrast, euxinic sediments in the Black Sea exhibit $\mathrm{Zn} / \mathrm{Al}$ ratios that are two to nine times higher than those in oxic sediments. In this study, the deep-water Wuhe and Xiangtan sections are interpreted to be deposited under ferruginous conditions with intermittent euxinic conditions (Han \& Fan, 2015; Sahoo et al., 2016). In anoxic conditions, isotopically heavy $\mathrm{Zn}$ adsorbed onto Fe-Mn oxides and organisms would have been released into seawater through the reduction of Fe-Mn oxides and degradation of the organisms, which could result in a heavier $\mathrm{Zn}$ isotope composition in deep water. This hypothesis is supported by several observations of $\delta^{66} \mathrm{Zn}$ values from the northeastern Atlantic and Southern Ocean (Atlantic sector), where seawater at intermediate depths exhibits a positive excursion of up to $0.7 \%$ (Conway \& John, 2014, 2015; Zhao et al., 2014). These observations from different modern oceans by different researchers indicate that $\mathrm{Zn}$ isotope fractionation associated with internal cycling resulted from the regeneration of isotopically heavy $\mathrm{Zn}$ adsorbed onto organisms and Fe-Mn oxides or the precipitation of isotopically light $\mathrm{Zn}$ in sulfides (Conway \& John, 2014, 2015; John \& Conway, 2014; Zhao et al., 2014). Heavier $\mathrm{Zn}$ isotope excursion at middepth seawater in the South Ocean may reflect regeneration of adsorbed $\mathrm{Zn}$ onto organism surfaces because oxygen supply is not low (John \& Conway, 2014). However, the shift in $\delta^{66} \mathrm{Zn}$ values to $0.6 \%$ at SAFe in North East Pacific Ocean was explained by sulfide precipitation (Conway \& John, 2014, 2015). Based on recent knowledge, we suggest that the lower $\delta^{66} \mathrm{Zn}$ values measured in slope and basinal sections could indicate a significant contribution by sulfide (sphaleritea/wurtzite) precipitation in ferruginous deep water of the early Ediacaran oceans (Figure 6). Noteworthy, the highest $\delta^{66} \mathrm{Zn}$ value $(0.45 \%$ ) in a euxinic black shale (WH43) may indicate that $\mathrm{Zn}$ isotope signal of anoxic seawater in the Nanhua basin was similar to that of modern deep seawater. More investigations will be needed to estimate $\mathrm{Zn}$ isotope composition of global deep seawater in a phosphorus-rich redox stratified ocean during the early Ediacaran. 


\section{Conclusion}

The $\mathrm{Zn}$ isotope compositions of the early Ediacaran shallow water phosphorite and dolostones and deep-water organic-rich shale, located in South China, were investigated in this study. The wide range of observed $\delta^{66} \mathrm{Zn}_{\text {Carb }}$ values in dolostone and phosphorite may reflect $\mathrm{Zn}$ isotope fractionation during the substitution of $\mathrm{Zn}$ into dolomite and the exchange of $\mathrm{Zn}$ between dolomite and phosphate, respectively, rather than seawater signals. Almost all phosphorites exhibit heavier $\mathrm{Zn}$ isotope composition than those pure dolostones. This observation may provide supporting evidence for previous theoretical calculations that demonstrate that the bonding of $\mathrm{Zn}$ with phosphate can enrich isotopically heavy $\mathrm{Zn}$ in $\mathrm{Zn}$ phosphate species. In the phosphorus-rich Edicaran ocean, the adsorption of $Z n$ by organisms may play an important role in increasing $\delta^{66} \mathrm{Zn}$ values in the lower phosphorite layers. In contrast, the inorganic processes (e.g., $\mathrm{Zn}$ bonding with Fe-Mn oxides) may enhance $\delta^{66} \mathrm{Zn}$ values in the upper phosphorite layers. The Weng'an biota preserved in the upper phosphorite did not significantly uptake light $\mathrm{Zn}$ isotope. These processes could also transfer isotopically heavy $\mathrm{Zn}$ into deep water. However, the deep-water organic-rich shales show light $\mathrm{Zn}$ isotope composition, similar to that of the continental crust, which may reflect $\mathrm{Zn}$ isotope fractionation during sulfide (sphalerite/wurtzite) precipitation in middepth environment. In a phosphorus-rich redox stratified ocean, phosphorite may be an important sink of heavy $Z n$ isotope, whereas those ferruginous black shale could be isotopically light $\mathrm{Zn}$ sink.

Acknowledgments

This project is funded by the Strategic Priority Research Program (B) of Chinese Academy of Sciences (XDB18030302), the National Basic Research Program of China (2014CB440906), the National Natural Science Foundation of China (41573011, 41430104), and the Youth Innovation Promotion Association CAS, CAS "Light of West China" Program, Geological Exploration Fund of Guizhou Province (2016-09-01). The data presented in this study are available as Table S1. We give thanks to Marcus Kunzmann and another anonymous reviewer for reviewing the manuscript.

\section{References}

Archer, C., \& Vance, D. (2004). Mass discrimination correction in multiple-collector plasma source mass spectrometry: An example using Cu and Zn isotopes. Journal of Analytical Atomic Spectrometry, 19(5), 656-665. https://doi.org/10.1039/b315853e

Archer, C., Vance, D., \& Lohan, M. (2016). Zinc and nickel isotope systematics in the South Atlantic Ocean. Goldschmidt abstract, Yokohama. Barfod, G. H., Albarède, F., Knoll, A. H., Xiao, S. H., Télouk, P., Frei, R., et al. (2002). New Lu-Hf and Pb-Pb age constraints on the earliest animal fossils. Earth and Planetary Science Letters, 201(1), 203-212. https://doi.org/10.1016/S0012-821X(02)00687-8

Brocks, J. J., Ajm, J., Sirantoine, E., Hallmann, C., Hoshino, Y., \& Liyanage, T. (2017). The rise of algae in cryogenian oceans and the emergence of animals. Nature, 548(7669), 578-581. https://doi.org/10.1038/nature23457

Bryan, A. L., Dong, S., Wilkes, E. B., \& Wasylenki, L. E. (2015). Zinc isotope fractionation during adsorption onto Mn oxyhydroxide at low and high ionic strength. Geochimica et Cosmochimica Acta, 157, 182-197. https://doi.org/10.1016/j.gca.2015.01.026

Chadwick, O. A., Derry, L. A., Vitousek, P. M., Huebert, B. J., \& Hedin, L. O. (1999). Changing sources of nutrients during four million years of ecosystem development. Nature, 397(6719), 491-497. https://doi.org/10.1038/17276

Chen, D. F., Dong, W. Q., Zhu, B. Q., \& Chen, X. P. (2004). Pb-Pb ages of Neoproterozoic Doushantuo phosphorites in South China: Constraints on early metazoan evolution and glaciation events. Precambrian Research, 132(1-2), 123-132. https://doi.org/10.1016/j. precamres.2004.02.005

Chen, D. F., Wei, Q. D., Liang, Q., Chen, G. Q., \& Xian, P. C. (2003). Possible REE constraints on the depositional and diagenetic environment of Doushantuo Formation phosphorites containing the earliest metazoan fauna. Chemical Geology, 201(1-2), 103-118. https://doi.org/ 10.1016/S0009-2541(03)00235-3

Conway, T. M., \& John, S. G. (2014). The biogeochemical cycling of zinc and zinc isotopes in the North Atlantic Ocean. Global Biogeochemical Cycles, 28, 1111-1128. https://doi.org/10.1002/2014GB004862

Conway, T. M., \& John, S. G. (2015). The cycling of iron, zinc and cadmium in the North East Pacific Ocean-Insights from stable isotopes. Geochimica et Cosmochimica Acta, 164, 262-283. https://doi.org/10.1016/j.gca.2015.05.023

Cook, P. J., \& Shergold, J. H. (1984). Phosphorus, phosphorites and skeletal evolution at the Precambrian-Cambrian boundary. Nature, 308(5956), 231-236. https://doi.org/10.1038/308231a0

Cox, G. M., Halverson, G. P., Stevenson, R. K., Vokaty, M., Poirier, A., Kunzmann, M., et al. (2016). Continental flood basalt weathering as a trigger for neoproterozoic snowball earth. Earth and Planetary Science Letters, 446, 89-99. https://doi.org/10.1016/j.epsl.2016.04.016

de Souza, G. F., Khatiwala, S. P., Hain, M. P., Little, S. H., \& Vance, D. (2018). On the origin of the marine zinc-silicon correlation. Earth and Planetary Science Letters, 492, 22-34. https://doi.org/10.1016/j.epsl.2018.03.050

Dong, S. F., \& Wasylenki, L. E. (2016). Zinc isotope fractionation during adsorption to calcite at high and low ionic strength. Chemical Geology, 447, 70-78. https://doi.org/10.1016/j.chemgeo.2016.10.031

Ducher, M., Blanchard, M., \& Balan, E. (2016). Equilibrium zinc isotope fractionation in Zn-bearing minerals from first-principles calculations Chemical Geology, 443, 87-96. https://doi.org/10.1016/j.chemgeo.2016.09.016

Dupont, C. L., Butcher, A., Valas, R. E., Bourne, P. E., \& Caetano-Anollés, G. (2010). History of biological metal utilization inferred through phylogenomic analysis of protein structures. Proceedings of the National Academy of Sciences, 107(23), 10,567-10,572. https://doi.org/ 10.1073/pnas.0912491107

Föllmi, K. B. (1996). The phosphorus cycle, phosphogenesis and marine phosphate-rich deposits. Earth Science Reviews, 40(1-2), 55-124. https://doi.org/10.1016/0012-8252(95)00049-6

Fujii, T., \& Albarède, F. (2012). Ab initio calculation of the $\mathrm{Zn}$ isotope effect in phosphates, citrates, and malates and applications to plants and soil. PLoS One, 7(2), e30726. https://doi.org/10.1371/journal.pone.0030726

Fujii, T., Moynier, F., Blichert-Toft, J., \& Albarède, F. (2014). Density functional theory estimation of isotope fractionation of Fe, Ni, Cu, and Zn among species relevant to geochemical and biological environments. Geochimica et Cosmochimica Acta, 140, 553-576. https://doi.org/ 10.1016/j.gca.2014.05.051

Fujii, T., Moynier, F., Pons, M.-L., \& Albarede, F. (2011). The origin of Zn isotope fractionation in sulfides. Geochimica et Cosmochimica Acta, 75(23), 7632-7643. https://doi.org/10.1016/j.gca.2011.09.036

Garnit, H., Bouhlel, S., Barca, D., \& Chtara, C. (2012). Application of La-ICP-MS to sedimentary phosphatic particles from Tunisian phosphorite deposits: Insights from trace elements and REE into paleo-depositional environments. Chemie der Erde - Geochemistry, 72(2), 127-139. https://doi.org/10.1016/j.chemer.2012.02.001 
Gélabert, A., Pokrovsky, O. S., Viers, J., Schott, J., Boudou, A., \& Feurtet-Mazel, A. (2006). Interaction between zinc and freshwater and marine diatom species: Surface complexation and Zn isotope fractionation. Geochimica et Cosmochimica Acta, 70(4), 839-857. https://doi.org/ 10.1016/j.gca.2005.10.026

Guo, Q.j., Liu, C. Q., Harald, S., Tatiana, G., \& Yang, W. D. (2005). Carbon isotopic bio-geochemical study on the section of Doushantuo Formation in Weng'an, Guizhou Province. Journal of Mineralogy and Petrology, 25(2), 75-80. (In Chinese with English abstract)

Han, T., \& Fan, H. F. (2015). Dynamic evolution of the Ediacaran Ocean across the Doushantuo Formation, South China. Chemical Geology, 417(1), 261-272. https://doi.org/10.1016/j.chemgeo.2015.09.021

Heggie, D. T., Skyring, G. W., O'Brien, G. W., Reimers, C., Herczeg, A., Moriarty, D. J. W., et al. (1990). Organic carbon cycling and modern phosphorite formation on the East Australia continental margin: An overview. In A. J. G. Notholt \& I. Jarvis (Eds.), Phosphorite research and development (pp. 87-117). Oxford: The Geological Society of London.

Hiatt, E. E., Pufahl, P. K., \& Edwards, C. T. (2015). Sedimentary phosphate and associated fossil bacteria in a paleoproterozoic tidal flat in the 1.85Ga michigamme formation, michigan, USA. Sedimentary Geology, 319, 24-39. https://doi.org/10.1016/j.sedgeo.2015.01.006

Horton, F. (2015). Did phosphorus derived from the weathering of large igneous provinces fertilize the Neoproterozoic Ocean? Geochemistry, Geophysics, Geosystems, 16, 1723-1738. https://doi.org/10.1002/2015GC005792

Jamieson-Hanes, J. H., Shrimpton, H. K., Veeramani, H., Ptacek, C. J., Lanzirotti, A., Newville, M., \& Blowes, D. W. (2017). Evaluating zinc isotope fractionation under sulfate reducing conditions using a flow-through cell and in situ XAS analysis. Geochimica et Cosmochimica Acta, 203, 1-14. https://doi.org/10.1016/j.gca.2016.12.034

Jarvis, I., Burnett, W. C., Nathan, Y., Almbaydin, F. S. M., Attia, A. K. M., Castro, L. N., et al. (1994). Phosphorite geochemistry: State-of-the-art and environmental concerns. Eclogae Geologicae Helveticae, 87(3), 643-700.

Jiang, G. Q., Shi, X. Y., Zhang, S. H., Wang, Y., \& Xiao, S. H. (2011). Stratigraphy and paleogeography of the Ediacaran Doushantuo Formation (ca. 635-551 Ma) in South China. Gondwana Research, 19(4), 831-849. https://doi.org/10.1016/j.gr.2011.01.006

John, S. G., \& Conway, T. M. (2014). A role for scavenging in the marine biogeochemical cycling of zinc and zinc isotopes. Earth and Planetary Science Letters, 394, 159-167. https://doi.org/10.1016/j.epsl.2014.02.053

John, S. G., Geis, R. W., Saito, M. A., \& Boyle, E. A. (2007). Zinc isotope fractionation during high-affinity and low-affinity zinc transport by the marine diatom Thalassiosira oceanica. Limnology and Oceanography, 52(6), 2710-2714. https://doi.org/10.4319/lo.2007.52.6.2710

John, S. G., Kunzmann, M., Townsend, E. J., \& Rosenberg, A. D. (2016). Zinc and cadmium stable isotopes in the geological record: A case study from the post-snowball earth Nuccaleena cap dolostone. Palaeogeography Palaeoclimatology Palaeoecology, 466, 202-208. https://doi. org/10.1016/j.palaeo.2016.11.003

Jouvin, D., Louvat, P., Juillot, F., Maréchal, C. N., \& Benedetti, M. F. (2009). Zinc isotopic fractionation: Why organic matters. Environmental Science and Technology, 43(15), 5747-5754. https://doi.org/10.1021/es803012e

Juillot, F., Maréchal, C., Ponthieu, M., Cacaly, S., Morin, G., Benedetti, M., et al. (2008). Zn isotopic fractionation caused by sorption on goethite and 2-lines ferrihydrite. Geochimica et Cosmochimica Acta, 72(19), 4886-4900. https://doi.org/10.1016/j.gca.2008.07.007

Knauth, L. P., \& Kennedy, M. J. (2009). The late Precambrian greening of the earth. Nature, 460(7256), 728-732. https://doi.org/10.1038/ nature08213

Köbberich, M., \& Vance, D. (2017). Kinetic control on Zn isotope signatures recorded in marine diatoms. Geochimica et Cosmochimica Acta, 210, 97-113. https://doi.org/10.1016/j.gca.2017.04.014

Konhauser, K. O., Lalonde, S. V., Amskold, L., \& Holland, H. D. (2007). Was there really an Archean phosphate crisis? Science, 315(5816), 1234-1234. https://doi.org/10.1126/science.1136328

Kunzmann, M., Halverson, G. P., Sossi, P. A., Raub, T. D., Payne, J. L., \& Kirby, J. (2013). Zn isotope evidence for immediate resumption of primary productivity after snowball earth. Geology, 41(1), 27-30. https://doi.org/10.1130/G33422.1

Li, C., Love, G. D., Lyons, T. W., Fike, D. A., Sessions, A. L., \& Chu, X. L. (2010). A stratified redox model for the Ediacaran ocean. Science, 328 , 80-83. https://doi.org/10.1126/science.1182369

Little, S. H., Sherman, D. M., Vance, D., \& Hein, J. R. (2014). Molecular controls on Cu and Zn isotopic fractionation in Fe-Mn crusts. Earth and Planetary Science Letters, 396, 213-222. https://doi.org/10.1016/j.epsl.2014.04.021

Little, S. H., Vance, D., Mcmanus, J., \& Severmann, S. (2016). Key role of continental margin sediments in the oceanic mass balance of $\mathrm{Zn}$ and Zn isotopes. Geology, 44(3), 207-210. https://doi.org/10.1130/G37493.1

Little, S. H., Vance, D., Walker-Brown, C., \& Landing, W. M. (2014). The oceanic mass balance of copper and zinc isotopes, investigated by analysis of their inputs, and outputs to ferromanganese oxide sediments. Geochimica et Cosmochimica Acta, 125(1), 673-693. https://doi. org/10.1016/j.gca.2013.07.046

Liu, S. A., Wu, H., Shen, S., Jiang, G., Zhang, S., Lv, Y., et al. (2017). Zinc isotope evidence for intensive magmatism immediately before the endPermian mass extinction. Geology, 45(4), 343-346. https://doi.org/10.1130/G38644.1

Maréchal, C., Nicolas, E., Douchet, C., \& Albarède, F. (2000). Abundance of zinc isotopes as a marine biogeochemical tracer. Geochemistry, Geophysics, Geosystems, 1(5), 1-15. https://doi.org/10.1029/1999GC000029

Moynier, F., Vance, D., Fujii, T., \& Savage, P. (2017). The isotope geochemistry of zinc and copper. Reviews in Mineralogy and Geochemistry, 82(1), 543-600. https://doi.org/10.2138/rmg.2017.82.13

Nelson, G. J., Pufahl, P. K., \& Hiatt, E. E. (2010). Paleoceanographic constraints on Precambrian phosphorite accumulation, Baraga group, Michigan, USA. Sedimentary Geology, 226(1-4), 9-21. https://doi.org/10.1016/j.sedgeo.2010.02.001

Pichat, S., Douchet, C., \& Albarède, F. (2003). Zinc isotope variations in deep-sea carbonates from the eastern equatorial Pacific over the last 175 ka. Earth and Planetary Science Letters, 210(1-2), 167-178. https://doi.org/10.1016/S0012-821X(03)00106-7

Planavsky, N. J., Rouxel, O. J., Bekker, A., Lalonde, S. V., Konhauser, K. O., Reinhard, C. T., \& Lyons, T. W. (2010). The evolution of the marine phosphate reservoir. Nature, 467(7319), 1088-1090. https://doi.org/10.1038/nature09485

Pokrovsky, O. S., Viers, J., \& Freydier, R. (2005). Zinc stable isotope fractionation during its adsorption on oxides and hydroxides. Journal of Colloid and Interface Science, 291(1), 192-200. https://doi.org/10.1016/j.jcis.2005.04.079

Pons, M. L., Fujii, T., Rosing, M., Quitté, G., Télouk, P., \& Albarède, F. (2013). A Zn isotope perspective on the rise of continents. Geobiology, 11(3), 201-214. https://doi.org/10.1111/gbi.12030

Pufahl, P. K., \& Grimm, K. A. (2003). Coated phosphate grains: Proxy for physical, chemical, and ecological changes in seawater. Geology, 31(9), 801-804. https://doi.org/10.1130/G19658.1

Qi, L., Hu, J., \& Gregoire, D. C. (2000). Determination of trace elements in granites by inductively coupled plasma mass spectrometry. Talanta 51(3), 507-513. https://doi.org/10.1016/S0039-9140(99)00318-5

Reinhard, C. T., Planavsky, N. J., Gill, B. C., Ozaki, K., Robbins, L. J., Lyons, T. W., et al. (2017). Evolution of the global phosphorus cycle. Nature, 541(7637), 386-389. https://doi.org/10.1038/nature20772 
Robbins, L. J., Lalonde, S. V., Planavsky, N. J., Partin, C. A., Reinhard, C. T., Kendall, B., et al. (2016). Trace elements at the intersection of marine biological and geochemical evolution. Earth Science Reviews, 163, 323-348. https://doi.org/10.1016/j.earscirev.2016.10.013

Robbins, L. J., Lalonde, S. V., Saito, M. A., Planavsky, N. J., Mloszewska, A. M., Pecoits, E., et al. (2013). Authigenic iron oxide proxies for marine zinc over geological time and implications for eukaryotic metallome evolution. Geobiology, 11(4), 295-306. https://doi.org/10.1111/ gbi.12036

Sahoo, S. K., Planavsky, N. J., Jiang, G., Kendall, B., Owens, J. D., Wang, X., et al. (2016). Oceanic oxygenation events in the anoxic Ediacaran Ocean. Geobiology, 14(5), 457-468. https://doi.org/10.1111/gbi.12182

Samanta, M., Ellwood, M. J., Sinoir, M., \& Hassler, C. S. (2017). Dissolved zinc isotope cycling in the Tasman Sea, SW pacific ocean. Marine Chemistry, 192, 1-12. https://doi.org/10.1016/j.marchem.2017.03.004

Scott, C., Planavsky, N. J., Dupont, C. L., Kendall, B., Gill, B. C., Robbins, L. J., et al. (2013). Bioavailability of zinc in marine systems through time. Nature Geoscience, 6(2), 125-128. https://doi.org/10.1038/NGEO1679

Shimura, T., Kon, Y., Sawaki, Y., Hirata, T., Han, J., Shu, D., et al. (2014). In-situ analyses of phosphorus contents of carbonate minerals: Reconstruction of phosphorus contents of seawater from the Ediacaran to early Cambrian. Gondwana Research, 25(3), 1090-1107. https:// doi.org/10.1016/j.gr.2013.08.001

Tang, S. H., Zhu, X. K., Cai, J. J., Li, S. Z., He, X. X., \& Wang, J. H. (2006). Chromatographic separation of Cu, Fe and Zn using AG M P-1 anion exchange resin for isotope determination by MC-ICPMS. Rock and Mineral Analysis, 25(1), 5-8. (in Chinesewith English abstract)

Tang, T., Love, G., Zumberge, A., Reinhard, C., Dupont, C. L., Asael, D., et al. (2016). Tracking the rise of eukaryotes to ecological dominance with zinc isotopes. In Goldschmidt Conference Abstracts p.3076.

Twining, B. S., \& Baines, S. B. (2013). The trace metal composition of marine phytoplankton. Annual Review of Marine Science, 5(1), 191-215. https://doi.org/10.1146/annurev-marine-121211-172322

Vance, D., Little, S. H., Archer, C., Cameron, V., Andersen, M. B., Rijkenberg, M. J. A., et al. (2016). The oceanic budgets of nickel and zinc isotopes: The importance of sulfidic environments as illustrated by the Black Sea. Philosophical Transactions of the Royal Society. A: Mathematical Physical And Engineering Sciences, 374(2081), 20150294. https://doi.org/10.1098/rsta.2015.0294

Vance, D., Little, S. H., de Souza, G. F., Khatiwala, S., Lohan, M. C., \& Middag, R. (2017). Silicon and zinc biogeochemical cycles coupled through the Southern Ocean. Nature Geoscience, 10(3), 202-206. https://doi.org/10.1038/ngeo2890

Veeramani, H., Eagling, J., Jamieson-hanes, J. H., Kong, L. Y., Ptacek, C. J., \& Blowes, D. W. (2015). Zinc isotope fractionation as an indicator of geochemical attenuation processes. Environmental Science \& Technology Letters, 2(11), 314-319. https://doi.org/10.1021/acs. estlett.5b00273

Wang, Z. Z., Liu, S. A., Liu, J. G., Huang, J., Xiao, Y., Chu, Z. Y., et al. (2017). Zinc isotope fractionation during mantle melting and constraints on the $\mathrm{Zn}$ isotope composition of Earth's upper mantle. Geochimica et Cosmochimica Acta, 198, 151-167. https://doi.org/10.1016/j. gca.2016.11.014

Wanty, R. B., Podda, F., Giudici, G. D., Cidu, R., \& Lattanzi, P. (2013). Zinc isotope and transition-element dynamics accompanying hydrozincite biomineralization in the Rio Naracauli, Sardinia, Italy. Chemical Geology, 337-338, 1-10. https://doi.org/10.1016/j.chemgeo.2012.11.010

Xiao, C. Y., Zhang, Z. W., He, C. Z., Wen, H. J., \& Fan, H. F. (2018). The depositional environment of Ediacaran phosphorite deposits, South China. Bulletin of Mineralogy, Petrology and Geochemistry, 37, 111-137. (in Chinese with English abstract). doi: https://doi.org/10.19658/j. issn.1007-2802.2018.37.007

Xiao, S. H., Knoll, A. H., Zhang, L. Y., \& Hua, H. (1999). The discovery of Wengania globosa in Doushantuo phosphorites in Chadian, Shaanx Province. Acta Micropalaeontologica Sinica, 16(3), 259-266.

Xiao, S. H., Muscente, A. D., Chen, L., Zhou, C. M., Schiffbauer, J. D., Wood, A. D., et al. (2014). The Weng'an biota and the Ediacaran radiation of multicellular eukaryotes. National Science Review, 1(4), 498-520. https://doi.org/10.1093/nsr/nwu061

Xiao, S. H., Zhang, Y., \& Knoll, A. H. (1998). Three-dimensional preservation of algae and animal embryos in a Neoproterozoic phosphorite. Nature, 391(6667), 553-558. https://doi.org/10.1038/35318

Zhao, Y., Vance, D., Abouchami, W., \& De Baar, H. J. W. (2014). Biogeochemical cycling of zinc and its isotopes in the Southern Ocean. Geochimica et Cosmochimica Acta, 125, 653-672. https://doi.org/10.1016/j.gca.2013.07.045

Zhou, C. M., Brasier, M. D., \& Xue, Y. S. (2001). Three-dimensional phosphatic preservation of giant acritarchs from the terminal Proterozoic Doushantuo Formation in Guizhou and Hubei provinces, South China. Palaeontology, 44(6), 1157-1178. https://doi.org/10.1111/14754983.00219 